FOLIA

Amazónica

Revista del Instituto de Investigaciones

de la Amazonía Peruana

\title{
CHEMICAL SOIL ATTRIBUTES IN DIFFERENT USE SYSTEMS, ITACOATIARA-AM, BRAZIL
}

\author{
Juan Daniel VILLACIS FAJARDO ${ }^{1 *}$, Ronald ALMEIDA FONSECA ${ }^{2}$, \\ Julio Cesar AMARAL CARDOSO ${ }^{3}$, Maila Thais VIEIRA MAIA ${ }^{3}$, \\ Márcia Mourão RAMOS AZEVEDO ${ }^{3}$, Paulo Sérgio TAUBE ${ }^{3}$, Ruy BESSA LOPES ${ }^{3}$, \\ José Augusto AMORIM SILVA DO SACRAMENTO ${ }^{3}$, Emerson CRISTI DE BARROS ${ }^{4}$, \\ Rodil TELLO ESPINOZA ${ }^{5}$, Nancy Andrea VILLACIS FAJARDO ${ }^{5}$ \\ 1 University of the State of Amapá, Campus Território dos Lagos, Macapá, AP, Brazil. \\ 2 University of the State of Amazonas, Escola Superior de Tecnologia de Itacoatiata, Itacoatiara, AM, \\ Brazil. \\ 3 Federal University of West Pará, Biodiversity and Forest Institute, Santarém, PA, Brazil. \\ ${ }^{4}$ Federal University of Viçosa, Department of Agricultural Engineering, Viçosa, MG, Brazil. \\ ${ }^{5}$ National University of the Peruvian Amazon, Iquitos, Loreto, Peru. \\ *Email: davifa2840@gmail.com
}

\begin{abstract}
The use of soil to implement several management systems, such as agriculture, livestock farming and agroforestry activities contribute to the depletion of the soil and the forest, reducing or increasing the levels of soil chemical attributes, such as calcium, magnesium, potassium, and phosphorus and increase or decrease of active $(\mathrm{pH})$ or exchangeable (Aluminum) acidity. This study aimed to evaluate macronutrients (calcium - $\mathrm{Ca}^{2+}$, magnesium $-\mathrm{Mg}^{2+}$, potassium $-\mathrm{K}^{+}$ and phosphorus - $\mathrm{P}$ ), as well as aluminum $-\mathrm{Al}^{3+}$ and soil $\mathrm{pH}$, under use systems: agroforestry system - SAFs and pasture - PA, comparing them to Primary Forest - PF, in the Rosenthal community in Itacoatiara-AM, Brazil. The soils were sampled in layers $0-10 \mathrm{~cm}$ and 10-20 cm deep, with samples composed of six single samples each. The distribution of nutrient contents $\left(\mathrm{C}^{\mathrm{a} 2+}, \mathrm{Mg}^{2+}, \mathrm{K}^{+}\right.$, and P) considering the 0-10 and 10-20 cm layers showed little variation, except for phosphorus, which obtained the highest concentration in the prospected layers. The distribution of calcium, magnesium, and potassium nutrients in the sampled soil layers decreased with depth. However, an inverse pattern was observed in
\end{abstract}


the elevation of active soil acidity and aluminium levels. Soil macronutrients showed medium to high concentrations, with forest and SAFs as systems that preserve good levels of fertility.

KEYWORDS: primary forest, agroforest systems, macronutrients, fertility.

\section{ATRIBUTOS QUÍMICOS DE SUELO EN SISTEMAS DE USOS DIFERENTE, ITACOATIARA-AM, BRASIL}

\section{RESUMEN}

El uso del suelo para implementar varios sistemas de gestión, como la agricultura, la ganadería y las actividades agroforestales contribuyen al agotamiento del suelo y del bosque, reduciendo o aumentando los niveles de los atributos químicos del suelo, como el calcio, el magnesio, el potasio y fósforo y aumento o disminución de la acidez activa $(\mathrm{pH})$ o intercambiable (aluminio). El objetivo de este estudio fue evaluar los macronutrientes (calcio $-\mathrm{Ca}^{2+}$, magnesio $-\mathrm{Mg}^{2+}$, potasio $-\mathrm{K}^{+}$ y fósforo -, P), así como aluminio $-\mathrm{Al}^{3}+\mathrm{y}$ pH del suelo, bajo sistemas de uso: sistema agroforestal - SAF y pastos - AP, comparándolos con el bosque primario - FP, en la comunidad Rosenthal en Itacoatiara, estado de Amazonas, Brasil. Los suelos se muestrearon en capas de 0-10 cm y 10-20 cm de profundidad, con muestras compuestas de seis muestras individuales cada una. La distribución del contenido de nutrientes $\left(\mathrm{Ca}^{2+}, \mathrm{Mg}^{2+}, \mathrm{K}^{+}\right.$y $\left.\mathrm{P}\right)$ considerando las capas de 0-10 y 10-20 cm mostró poca variación, a excepción del fósforo, que obtuvo la concentración más alta en las capas prospectadas. La distribución de nutrientes de calcio, magnesio y potasio en las capas de suelo muestreadas disminuyó con la profundidad. Sin embargo, se observó un patrón inverso en la elevación de la acidez activa del suelo y los niveles de aluminio. Los macronutrientes del suelo tienen concentraciones de media a altas, con bosques y SAFs como sistemas que preservan buenos niveles de fertilidad.

PALABRAS CLAVES: bosque primario, sistema agroforestal, macronutrientes, fertilidad. 


\section{INTRODUCTION}

Oxisols and Ultisols, characterized as deep soils, with high weathering and low fertility, correspond to about $60 \%$ of the soils of the northern Brazilian region (Santos etal., 2011). The Amazon region has two predominant physiographic environments: a region of plateaus never flooded and a region of floodplains, located in the region of plains that border the rivers of the region and which is often flooded (Moreira \& Fageria, 2009). This plateau region represents more than $75 \%$ of the territory and features deep, acidic, highly weathered soils, low fertility and low cation exchange capacity (CEC), in addition to being composed of low activity silicates. In turn, the floodplain region has high levels of sediments, clay and sand, high cation exchange capacity, and base saturation (Quesada et al., 2009).

With regard land-use systems, primary forest is considered the most important ecosystem, since it is characterized by little human interference (Brown et al., 2020). However, with the increase in agricultural and livestock activities, it has a significant reduction in its area every year (Sarkar etal.,2020; Siqueira-Gay etal., 2020). This primary forest has a dense, deep, and permanent network of roots that allows nutrient cycling. Besides, the dossal of trees and litter protect the soil against erosion and high temperatures (Landi \& Renison, 2010; Weiler et al., 2019).

Agroforestry systems (SAFs) are considered models of land use that most closely match the characteristics of the natural forest, thus being considered important alternatives for sustainable use of the humid tropical ecosystem (Gomes et al., 2020; Phondani et al., 2020). In natural and conventional agricultural systems, the plant biomass that forms the litter is basically the senescent matter. The SAFs are distinguished from these systems since the presence of tree forest components added to a great biodiversity of plant species, enables the continuous decomposition of plant biomass, facilitating the maintenance of organic matter as well as soil nutrients (Oelbermann et al., 2006; Delabie et al., 2007; Iwata et al., 2012).

Both in the forest and the SAFs, the permanence of the litter contributes to the reuse in the nutrient cycle of the ecosystems, through its decomposition and the release of the constituent minerals and for later reabsorption by the plant roots (Schumacher et al., 2003; Giácomo et al., 2008; Caron et al., 2019). SAFs has been recommended as a solution and/or alternative for the recovery of degraded areas, with the potential to generate greater agricultural, forestry, and livestock productivity and also as a risk-reducing mechanism for the farmer (Caron et al., 2019).

However, in the Amazon region, disorderly occupation and lack of land use planning and management of natural resources have favoured deforestation and illegal logging (Sant'Anna \& Young, 2010; Ferreira et al., 2012). In addition to conventional (family) agriculture, the expansion of extensive livestock has been causing changes in large extensions of native Amazonian forests. Often the inadequate management of these soils for agricultural activities leads to the depletion of nutrients and changes in their physical properties, making them unproductive (Mendonça et al., 2013; Medeiros et al., 2016).

Thus, agricultural practices employed in temperate regions, such as the use of short-cycle annual plant monocultures, are inappropriate for tropical regions. Therefore, due to the high complexity of ecological interactions, the Amazon region requiring an ecological reassessment of tropical agriculture and environmental management (Fonte et al., 2014).

In the traditional management to which the Amazonian soil is subjected, means and alternatives of sustainable land use are sought, taking into account that the soils of this region, 
naturally already have low fertility. In this sense, the present work aimed to evaluate some chemical attributes (macronutrients $\mathrm{Ca}^{2+}, \mathrm{Mg}^{2+}, \mathrm{K}^{+}$, and $\mathrm{P} ; \mathrm{pH}, \mathrm{Al}^{3+}$ ) in the superficial layers of the soil, under two different types of use: Agroforestry system and Pasture, comparing them to the Primary Forest. After evaluating these attributes, the sustainability potential of each of the studied systems was assessed.

\section{MATERIAL AND METHODS}

\section{STUDY AREA}

The work was carried out in the Rosenthal community in the municipality of Itacoatiara, State of Amazonas, Brazil. Soil samples were collected between June and August 2009 in two different use systems:agroforestrysystem(SAFs) (32ㅜㄴ $47,3^{\prime \prime} \mathrm{S}$; $58^{\circ} 26 ` 56,7^{\prime \prime}$ ) (with approximately 5 years of use) and pasture ( $3^{\circ} 24^{\prime} 38,4^{\prime \prime} \mathrm{S}$; 58 $26^{\circ} 59,2^{\prime \prime} \mathrm{W}$ ) (with approximately 7 years of use), and compared to these two systems the primary forest (324`45,4“S; 58²7`06,9“W). Table 1 shows a general description of the areas selected for collecting soil samples.

The dominant climate in the region is classified as hot and humid tropical "Aw" (rainy summer with dry winter), which corresponds to tropical climates. The average annual temperature values range between $29^{\circ}$ and $34^{\circ} \mathrm{C}$. Relative air humidity indexes are rarely less than $70 \%$, oscillating around $90 \%$. The lowest monthly rainfall is always greater than $60 \mathrm{~mm}$, and the total rainfall is generally greater than 2,000 mm (Dubreuil et al., 2018).

The period of greatest rainfall in the region ranges from December to March, with an average rainfall of $254.5 \mathrm{~mm}$. The dry period extends from June to November with an average rainfall of 77.5 $\mathrm{mm}$. The region has an average annual rainfall of $1976.7 \mathrm{~mm}$ and the average total evaporation is
$595.4 \mathrm{~mm}$ per year. The average annual relative humidity is $82 \%$, the average annual total sunshine is 1781.7 hours (CPRM, 2018).

\section{Soil chemical analysis}

In each land-use system, an area of approximately $45 \times 15$ m was demarcated, divided into three subplots. In the smaller area (mainly in the case of SAFs), the total area considered as a parcel was divided in the same way corresponding to the repetitions. Soil samplings were carried out with the aid of a Dutch auger with a 3" diameter, and six soil samples were collected in each plot for each depth (0-10 and 10-20 cm). Afterward, the six samples from each plot were homogenized to form a composite sample. The soil samples were packed in plastic bags and transported to the greenhouse of the Instituto Nacional de Pesquisas da Amazônia, Coordenação de Pesquisas em Ciências Agronômicas - INPA/CPCA, in Manaus, $\mathrm{AM}$, where they were air-dried and homogenized. Subsequently, the soil was sieved in a $2 \mathrm{~mm}$ mesh to obtain air-dried fine soil (ADFS). Soil analyses were conducted at INPA's Thematic Soil and Plants Laboratory, on the V-8 Campus in Manaus, Brazil.

The following chemical attributes of the soil were determined: $\mathrm{pH}$ in water, phosphorus, potassium, calcium, magnesium, and aluminum. The $\mathrm{pH}$, phosphorus, potassium, calcium, magnesium, and aluminum were determined according to methods described and compiled by Embrapa (2017).

The $\mathrm{pH}$ of the soil in water was determined by the potentiometric method, using a suspension of soil in water in the proportion (1: 2.5, w/v). To determine the levels of $\mathrm{Ca}^{2+}, \mathrm{Mg}^{2+}$, and $\mathrm{Al}^{3+}$, $\mathrm{KCl} 1 \mathrm{~mol} \mathrm{~L}^{-1}$ was used as an extracting solution. For the determination of $\mathrm{K}+$ and phosphorus contents, the Melich I extractor $\left(_{2} \mathrm{SO}_{4} 0.05\right.$ mol L-1 $+\mathrm{HCl} 0.0125 \mathrm{~mol} \mathrm{~L}^{-1}$ ) was used in the proportion 1:10 (w/v). After extraction, the levels of $\mathrm{Ca}^{2+}, \mathrm{Mg}^{2+}, \mathrm{Al}^{3+}$, and $\mathrm{K}^{+}$were determined by 
atomic absorption spectrometry. Phosphorus contents were determined by spectrophotometry at a wavelength of $660 \mathrm{~nm}$. All analyzes were performed in triplicate.

\section{Particle Size Analysis}

The granulometric analysis was determined according to the methodology described by Donagema et al. (2017), which recommends that $50 \mathrm{~g}$ of soil should be dispersed in $0.038 \mathrm{~mol} \mathrm{~L}^{-1}$ aqueous sodium hexametaphosphate solution plus sodium hydroxide $\left(0.1 \mathrm{~mol} \mathrm{~L}^{-1}\right)$, by stirring for 18 hours. The suspension is transferred to test tubes with two readings made with Bouyoucos densimeter.

\section{Statistical analysis of the data}

For the interpretation of the results, the chemical determinations were considered separately for the different uses of the soil, as well as for the depths of $0-10,10-20 \mathrm{~cm}$, in the systems of use of the soil and, for both, the design was applied entirely randomized (DIC). The combination of 03 types of land use, with 2 depths, in a $3 \times 2$ factorial arrangement, and three repetitions (Factor A: land use: Factor B: soil depth) was considered. Aluminum data, absent in some soil horizons, were transformed to $\sqrt{\mathrm{x}}+0.01$. For comparisons between means, the Tukey test was adopted, at the level of $1 \%$ probability $(\mathrm{P}<0.01)$. For data statistics, the program used was Stat Unesp, Jaboticabal, SP.

\section{RESULTS AND DISCUSSION}

The concentration of nutrients in the soil depends on several factors, such as species composition, physiological conditions, and soil fertility. According to the results shown in Table 3, it can be seen that the distribution of nutrients in the superficial layer $(0-20 \mathrm{~cm})$ in the three land-use systems, showed little variation.
In natural and conventional agricultural systems, the plant biomass that forms the litter is basically the senescent matter. The SAFs are distinguished from these systems since the presence of tree forest components added to a great biodiversity of plant species, enables the continuous decomposition of plant biomass, facilitating the maintenance of organic matter as well as soil nutrients (Oelbermann et al., 2006; Delabie et al., 2007; Iwata et al., 2012).

The $\mathrm{pH}$ was strongly acid with values around 4.65 , with no significant variation in the two depths analyzed (Embrapa, 2018). Falcão \& Silva (2004) also found very low pH values in soils in the Central Amazon, varying between 4.00 and 4.70. The levels of aluminum present in these soils were considered average (Cunha et al., 2015). The levels of exchangeable cations $\mathrm{Ca}^{2+}, \mathrm{Mg}^{2+}$, and $\mathrm{K}^{+}$ showed average levels in the analyzed samples (Table 2).

The high levels of phosphorus found to differ from the low levels of phosphorus normally found in Oxisols in the region, which vary, on average, from 7 to $12 \mathrm{mg} \mathrm{kg}^{-1}$ of soil, Moline \& Coutinho (2015), which may suggest that the area could be an area of "Terra Preta Amazônica" (Amazonian Dark Earth) (Falcão et al., 2003; Silva et al., 2019).

The sum of exchangeable bases was above 1.5 cmolc $\mathrm{kg}^{-1}$ for both depths, showing a significant difference concerning the data obtained by Falcão \& Silva (2004), who found values below 1 cmolc $\mathrm{kg}^{-1}$. In general, fertility levels were considered medium to low (Cunha et al., 2015).

Calcium, in the soil, occurs predominantly in an exchangeable form, most of which is adsorbed to clay mineral with high CEC. Its average content in soils is between 1 and $2 \%$. The contents of $\mathrm{Mg}^{2+}$ were similar to the contents of $\mathrm{Ca}^{2+}$ about the different uses of the soil, and this presented itself as the second base in quantity in the total sum of bases in the soil (Iwata et al., 2012). 
Table 1. Description of the areas selected for sampling in the two land-use systems and the primary forest, located in the Rosenthal community, Arari river, Itacoatiara-AM, Brazil.

\begin{tabular}{cc}
\hline Use of the soil & Area Description \\
\hline Forest & Virgin forest, about $30 \mathrm{~m}$ high, climax, without disturbances. \\
Pasture & Cattle pasture, with bouncy grass, with 7 years of implantation. \\
SAFs & Agroforestry Systems, with 5 years with cocoa, açaí, and cupuaçu, with a predominance of \\
& andiroba. \\
\hline
\end{tabular}

Tabla 2. Evaluation of chemical attributes in the superficial layers of firm ground, collected in three land-use systems, in the Rosenthal community, Itacoatiara-AM, Brazil.*

\begin{tabular}{ccccc}
\hline \multirow{2}{*}{ Chemical attributes } & \multicolumn{2}{c}{ Depth of soil $(\mathrm{cm})$} & Coef. de var. (\%) & F test \\
\hline $\mathrm{pH}$ & $0-10$ & $10-20$ & 4.2 & $\mathrm{NS}$ \\
$\mathrm{Ca}^{2+}\left(\mathrm{cmol}_{c} \mathrm{~kg}^{-1}\right)$ & $4.63 a$ & $4.73^{\mathrm{a}}$ & 37.2 & $\mathrm{NS}$ \\
$\mathrm{Mg}^{2+}\left(\mathrm{cmol}_{c} \mathrm{~kg}^{-1}\right)$ & $5.28 \mathrm{a}$ & $3.80^{\mathrm{a}}$ & 60.5 & $\mathrm{NS}$ \\
$\mathrm{K}^{+}\left(\mathrm{cmol}_{c} \mathrm{~kg}^{-1}\right)$ & $0.77 a$ & $0.56^{\mathrm{a}}$ & 32.4 & $\mathrm{NS}$ \\
$\mathrm{P}\left(\mathrm{mg} \mathrm{kg}^{-1}\right)$ & $0.133 a$ & $0.098^{\mathrm{a}}$ & 110.7 & $\mathrm{NS}$ \\
$\mathrm{Al}^{3+}\left(\mathrm{cmol}_{c} \mathrm{~kg}^{-1}\right)$ & $211.2 \mathrm{a}$ & $224.6^{\mathrm{a}}$ & 10.4 & $\mathrm{NS}$ \\
\hline
\end{tabular}

* Means followed by the same letter in lines do not differ from each other at the $1 \%$ probability level $(P<0.01)$ by Tukey's test; NS: not significant.

Tabla 3. Distribution of the granulometric fraction of the soil in the community of Rosenthal, Itacoatiara-AM, Brazil.

\begin{tabular}{|c|c|c|c|c|c|}
\hline \multirow{2}{*}{ Systems } & \multirow{2}{*}{ Depth (cm) } & Coarse sand & Thin sand & Silte & Clay \\
\hline & & \multicolumn{4}{|c|}{$\%$} \\
\hline \multirow{2}{*}{ Forest } & $0-10$ & 9.62 & 14.59 & 11.13 & 64.66 \\
\hline & $10-20$ & 8.32 & 13.61 & 8.26 & 69.81 \\
\hline \multirow{2}{*}{ Pasture } & $0-10$ & 9.69 & 16.32 & 8.13 & 65.85 \\
\hline & $10-20$ & 7.83 & 15.47 & 9.13 & 67.57 \\
\hline \multirow{2}{*}{ SAFs } & $0-10$ & 18.28 & 20.95 & 19.04 & 41.72 \\
\hline & $10-20$ & 18.64 & 19.88 & 14.48 & 47.00 \\
\hline
\end{tabular}


The observed levels of $\mathrm{Ca}^{2+}$ and $\mathrm{Mg}^{2+}$ were considered low $\left(<2.0\right.$ and $<0.5$ cmolc $\mathrm{kg}^{-1}$, respectively) and restrictive to mineral nutrition of plants. These values were similar to those obtained by Araújo et al., (2005), studying in forest areas, pupunha plantations, and pasture. $\mathrm{Mg}^{2+}$ contents varied widely between systems in the same location. The data did not show significant differences for $\mathrm{Mg}^{2+}$ between the three systems.
The highest levels of $\mathrm{Ca}^{2+}, \mathrm{Mg}^{2+}$, and phosphorus in the soil were observed in the SAFs, cultivated with fruit species (Figure 1). It is important to note that the calcium levels were significantly different in the three land-use systems. In a study carried out by Embrapa (2017), calcium levels ( 0.16 to $0.24 \mathrm{cmolc}_{\mathrm{kg}}^{-1}$ ) were found to be similar between forest and pasture, however, their levels were higher in the SAFs $\left(12,97 \mathrm{cmol}_{\mathrm{c}} \mathrm{kg}^{-1}\right)$.
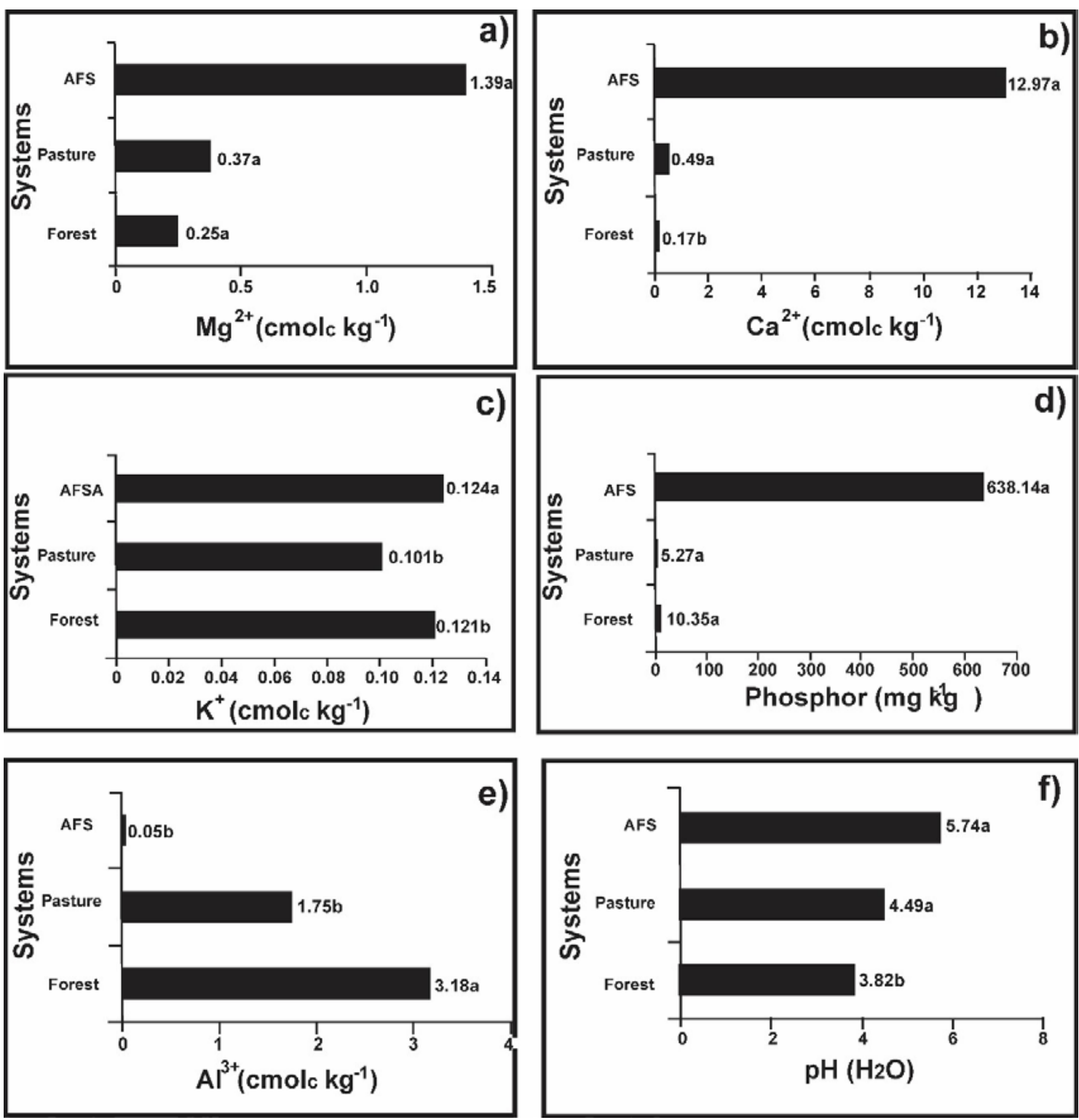

Figure 1. Macronutrient contents and $\mathrm{pH}$ values for different land-use systems in Itacoatiara-AM, Brazil. a) Mg²+, b) $\mathrm{Ca}^{2+}$, c) $\mathrm{K}^{+}$, d) Phosphorus, e) $\mathrm{Al}^{3+}$, f) $\mathrm{pH}(\mathrm{H} 2 \mathrm{O})$. No gráfico "d" alterar phosphor para phosphorus. 
About $100 \%$ of the total $\mathrm{K}^{+}$in the soil is in an exchangeable form, which is poorly absorbed by soil clays, thus being easily absorbed by plants and also conducive to leaching (Silva et al., 2018). For $\mathrm{K}^{+}$, there was a significant increase $(\mathrm{p}<0.01)$ in the concentration between the systems studied. However, despite showing similar values between forest and SAFs, the latter was significant among the other systems. The potassium contents found in this work were similar to those found by Araújo et al., (2005), studying forest area systems, however, a difference was observed for pupunha and pasture plantations.

Likewise, levels of phosphorus presented by Araújo et al., (2005), showed a greater increase in the pasture. In this study, the best results for this nutrient were found in the area of SAFs. The data are shown in the systems, despite not showing significant differences, the phosphorus was higher in the forest and the SAFs, with values considered high (Figure 1).

The behavior of the concentration of phosphorus in the sampled places tended to decrease in the pasture, and possibly occurring the nutrient release processes, considering the behavior of the acidity to increase in this sense, the samples, for the phosphorus, presented high fertility. The aluminium in the soil is contained in the structure of numerous primary and secondary minerals. The content of exchangeable or nonexchangeable aluminium depends directly on the $\mathrm{pH}$ of the soil, the lower this value the greater the dissolution of the minerals containing aluminium, releasing them in solution (Chaves et al., 2020).

The highest levels of exchangeable $\mathrm{Al}$ were found in forest and pasture systems, with values greater than $1.5 \mathrm{cmolc} \mathrm{kg}^{-1}$. Only in the SAFs, the aluminium contents were classified as low (Figure 1).

It is possible to observe the $\mathrm{pH}$ contrast with aluminium (Figure 1), its values were variable, being lower concerning the forest (3.82), followed by pasture (4.49), considered of high acidity, however for SAFs (5.74), the concentration was moderately acidic. The results obtained in the study show high acidity in most of the analyzed soil samples. It is possible that in SAFs and pasture, the cultural practices adopted, which include burning biomass before planting, may increase the availability of compounds that neutralize $\mathrm{Al}^{3+}$, which also include small increases in soil $\mathrm{pH}$ levels (Silva et al., 2011; Iwata et al., 2012).

The soils, in general, present high levels of coarse sand, with a predominantly sandy, loam-sandy, loam-sandy-clay, and sandy-clay texture (Donagema et al., 2016). The texture determines variations in soil characteristics, with consequences for management.

Most soil samples showed high sand fraction, with the highest content present in the SAFs sampled. The clay contents varied from 41.72 to $69.81 \%$ and those of silt from 8.13 to $19.04 \%$. In general, it was observed that the clay content increased with depth in the three different types of land use. The lowest fraction of silt was found in the pasture (Table 3).

\section{CONCLUSION}

The distribution of nutrient contents $\left(\mathrm{Ca}^{2+}, \mathrm{Mg}^{2+}, \mathrm{K}^{+}\right.$, and $\mathrm{P}$ ), considering the $0-10$ and $10-20 \mathrm{~cm}$ layers showed little variation, except for phosphorus, which obtained a higher concentration in the prospected layers.

The distribution of nutrients calcium, magnesium, and potassium, in the soil layers sampled, decreased with depth. However, there was an inverse pattern in the elevation of the soil's active acidity and aluminium levels.

The macronutrients showed medium to high concentrations in the soil, highlighting the forest and the SAFs as systems that preserve good levels of fertility. 


\section{BIBLIOGRAPHIC REFERENCES}

Araújo, G.H. de S.; Almeida, J.R. de.; Guerra, A.J.T. 2005. Gestão ambiental de áreas degradadas. Bertrand, Rio de Janeiro, Brasil, 320pp.

Brown, H.C.A.; Berniger, F.A.; Larjavaara, M.; Appiah, M. 2020. Above-ground carbon stocks and timber value of old timber plantations, secondary and primary forest in southern Ghana. Forest Ecology and Management, 472: 118236. DOI: https://doi.org/10.1016/j. foreco.2020.118236

Caron, B.O.; Pinheiro, M.V.M.; Korcelski, C.; Schwerz, F.; Elli, E.F.; Sgarbossa, J.; Tibolla, L.B. 2019. Agroforestry systems and understory harvest management: the impact on growth and productivity of dual-purpose wheat. Anais da Academia Brasileira de Ciências, 91(4): e20180667. DOI: https://doi. org/10.1590/0001-3765201920180667

Chaves, S.F.D.; Gama, M.A.P.; Alves, R.M.; Oliveira, R.P.; Pedroza Neto, J.L.; Lima, V.M.N. 2020. Evaluation of physicochemical attributes of a yellow latosol under agroforestry system as compared to secondary forest in the Eastern Amazon. Agroforestry Systems, 94(5): 19031912. DOI: https://doi.org/10.1007/s10457020-00513-6

CPRM Serviço Geológico do Brasil. 2018. Boletim de monitoramento hidrometeorológico da Amazônia Ocidental $n^{\circ}$ 14. CPRM, Manaus, 13pp.

Cunha, G.O.M.; Almeida, J.A.; Testoni, S.A.; Barboza, B.B. 2015. Forms of aluminum in brazilian acid soils with exceptionally high levels of KCIextractable $\mathrm{Al}^{3+}$. Revista Brasileira de Ciência do Solo, 39(5): 1362-1377. DOI: https://doi. org/10.1590/01000683rbcs20150017

Delabie,J.H.C.;Jahyny, B.; Nascimento, I.C.; Mariano, S.F.; Lacau, S.; Campiolo, S. 2007. Contribution of cocoa plantations to the conservation of native ants (Insecta: Hymenoptera: Formicidae) with a special emphasis on the Atlantic forest fauna of southern Bahia, Brazil. Biodiversity Conservation, 16: 2359-2384. DOI: https://doi. org/10.1007/s10531-007-9190-6

Donagema, G.K.; Viana, J.H.M.; Almeida, B.V.; Ruiz, H.A.; Klein, V.A.; Dechen, S.F.C.; Fernandes, F.B.A. 2017. Análise granulométrica. In: Texeira, P.C.; Donagema, G.K.; Fontana, A.; Texeira, W.G. (Eds.) Manual de métodos de análise de solo, 3aed. Embrapa, Brasília. p. 95-116.

Donagema, G.K.; Freitas, P.L.; Balieiro, F.C.; Fontana, A.; Spera, S.T.; Lumbreras, J.F.; Viana, J.H. M., Araújo Filho, J.C.; Santos, F.C.; Albuqerque, M.R.; Macedo, M. C. M.; Texeira, P. C.; Amaral, A. J.; Bortolon, E.; Bortolon, L. 2016. Caracterização, potencial agrícola e perspectivas de manejo de solos leves no Brasil. Pesquisa Agropecuária Brasileira, 51(9): 1003-1020. DOI: https://10.1590/S0100204X2016000900001

Dubreuil, V.; Fante, K. P.; Planchon, O.; Sant'Anna Neto, J. L. 2018. The types of annual climates in Brazil: an application of the classification of Köppen from 1961 to 2015. Revista FrancoBrasileira de Geografia, 37: 15738. DOI: https://doi.org/10.4000/confins.15738

Embrapa. 2018. Empresa Brasileira de Pesquisa Agropecuária. Sistema Brasileiro de Classificação de solo. 5a ed. Embrapa, Brasília, DF. 355pg.

Embrapa. 2017. Empresa Brasileira de Pesquisa Agropecuária. Manual de Métodos de Análise de solo. 3a ed. Embrapa, Brasília, DF. 575pg.

Falcão, N.P.S.; Comerford, N.; Lehmann, J. 2003. Determining nutrient bioavailability of Amazonian dark earth soils: methodological challenges. In: Lehmann, J. et al. (Ed). Amazonian dark earths: origins, properties, management. Kluwer, Boston. p. 255-270.

Falcão, N.P.S.; Silva, J.R.A. 2004. Características de adsorção de fósforo em alguns solos da 
Amazônia Central. Acta Amazônica, 34(3): 337-342.

Ferreira, L.V.; Pereira. J.L. G.; Cunha, D.A.; Matos, D.C.L.; Sanjuan, P.M. 2012. The Amazon is suitable for forestry, and the creation of new States can lead to increased deforestation in the Brazilian Amazon. Estudos Avançados, 26(74): 187-200. DOI: https://doi.org/10.1590/ S0103-40142012000100013

Fonte, S.J.; Nesper, M.; Hegglin, D.; Velásques, J.E.; Ramirez, B.; Rao, I.M.; Bernasconi, S.M.; Bunemann, E.K.; Frossard, E.; Oberson, A. 2014. Pasture degradation impacts soil phosphorus storage via changes to aggregate-associated soil organic matter in highly weathered tropical soils. Soil Biology and Biochemistry, 68: 150-157. DOI: https://doi.org/10.1016/j. soilbio.2013.09.025

Giácomo, R.G.; Pereira, M.G.; Balieiro, F.D.C. 2008. Estoques de carbono e nitrogênio e distribuição das frações húmicas no solo sob diferentes coberturas florestais. Revista Brasileira de Ciências Agrárias, 3(1): 42-48.

Gomes, L.C.; Bianchi, F.J.J.A.; Cardoso, I.M.; Fernandes, R.B.A.; Fernandes Filho, E.I.; Schulte, R.P.O. 2020. Agroforestry systems can mitigate the impacts of climate change on coffee production: A spatially explicit assessment in Brazil. Agriculture, Ecosystems and Environment Journal, 294: 106858. DOI: https://doi.org/10.1016/j.agee.2020.106858

Iwata, B.F.; Leita, L.F.C.; Araújo, A.S.F.; Nunes, L.A.P.; Gerhring, C.G.; Campos, L.P. 2012. Sistemas agroflorestais e seus efeitos sobre os atributos químicos em Argissolo Vermelho-Amarelo do Cerrado piauiense. Revista Brasileira de Engenharia Agrícola e Ambiental, 16(7): 730738. DOI: https://doi.org/10.1590/S141543662012000700005

Landi, M.A.; Renison, D. 2010. Forestación con Polylepis australis en suelos erosionados de las Sierras Grandes de Córdoba: evaluación del uso de terrazas y vegetación nodriza. Ecología Austral, 20: 47-55.

Medeiros, G.O.R.; Giarolla, A.; Sampaio, G.; Marinho, M.A. 2016. Diagnosis of the acclerated soil erosion in São Paulo state (Brazil) by the soil lifetime index methodology. Revista Brasileira de Ciência do Solo, 40: e0150498. DOI: https:// doi.org/10.1590/18069657rbcs20150498

Mendonça, V.Z.; Mello, L.M.M.; Andreotti, M.; Pereira, F.C.B.L.; Lima, R.C.; Valério Filho, W.V.; Yano, E.H. 2013. Evaluation of soil physical properties in a forage-corn intercropping in succession with soybean in the cerrado region. Revista Brasileira de Ciência do Solo, 37: 251259. DOI: https://doi.org/10.1590/S010006832013000100026

Moreira, A.; Fageria N. K. 2009. Soil chemical attributes of Amazonas state, Brazil. Communications in Soil Science and Plant Analysis, 40: 2912-2925.

Oelbermann, M.; Voroney, R.P.; Thevathasan, N.V.; Gordon, A.M.; Kass, D.C.L.; Schlonvoigt, A.M. 2006. Soil carbon dynamics and residue stabilization in a Costa Rican and southern Canadian alley cropping system. Agroforestry System, 68: 27-36. DOI: https://doi. org/10.1007/s10457-005-5963-7

Phondani, P.C.; Maikhuri, R.K.; Rawat, L.S.; Negi, V.S. 2020. Assessing farmers' perception on criteria and indicators for sustainable management of indigenous agroforestry systems in Uttarakhand, India. Environmental and Sustainability Indicators, 5: 100018. DOI: https://doi.org/10.1016/j.indic.2019.100018 Quesada, C.A.; Loyd, J.; Anderson, L.O.; Fyllas, N.M.; Schwarz, M.; Czimczik, E.C.I. 2009. Soils of Amazonia with particular reference to the rainfor sites, Biogeosciences, 6: 3851-3921. DOI: https://doi.org/10.5194/bg-8-14152011 
Sant'Anna, A.A.; Yougn, C.E.F. 2010. Direitos de propriedade, desmatamento e conflitos rurais na Amazônia. Economia Aplicada, 14(3): 381393. DOI: https://doi.org/10.1590/S141380502010000300006

Santos, H.G.; Carvalho Jinior, W.; Dart, R.O.; Aglio, M.L.D.; Sousa, J.S.; Pares, J.G.; Fontana, A.; Martins, A.L.S.; Oliveira, A.P. 2011. O novo mapa de solos do Brasil: legenda atualizada. Embrapa Solos, Rio de Janeiro. 67pp.

Sarkar, P.; Salami, M.; Githiora, Y.; Vieira, R.; Navarro, A.; Clavijo, D.; Padgurschi, M. 2020. A conceptual model to understand the drivers of change in tropical wetlands: a comparative assessment in India and Brazil. Biota Neotropica, 20: e20190913. DOI: https://doi. org/10.1590/1676-0611-bn-2019-0913

Schumacher, M.V.; Brun, E.J.; Rodrigues, L.M.; Santos, E.M. 2003. Retorno de nutrientes via deposição de serapilheira em um povoamento de acácia-negra (Acácia mearnsii de Wild.) no estado do Rio Grande do Sul. Revista Arvore, 27: 791-798.

Silva, C.; Marx, L.N.S.; Curi, N.; Oliveira, A.H.; Souza, F.S.; Martins, S.G.; Macedo, R.LG. 2011. Atributos do solo em sistemas agroflorestais, cultivo convencional e floresta nativa. Revista de Estudos Ambientais, 13(1): 77-8.

Silva, D.S.; Cardoso, J.C.A.; Lima, B.C.C.; Vasconcelos, A.A.; Rebellato, L.; Schaan, D.P.; Gomes, D.M.C.; Couto, R.R.; Brunetto, G.; Taube, P.S. 2018. Chemical characteristics of Amazonian dark earth in Santarem, Brazil. Brazilian Journal of Analytical Chemistry, 5(20): 35-47. DOI: http://dx.doi.org/10.30744/ brjac.2179-3425.2018.5.20.35-47

Silva, A.C.; Asis, W.S. 2019. Sistemas agroflorestais: limites e potencialidades no contexto sóciopolítico ambiental do sudeste paraense. Agroecossistemas, 1(1): 7-7.

Siqueira-Gay, J.; Yanai, A.M.; Lessmann, J.; Pessôa, A.C.M.; Borja, D.; Canova, M.; Borges, R.C. 2020. Pathways to positive scenarios for the Amazon forest in Pará state, Brazil. Biota Neotropica, 20: e20190905. DOI: https://doi. org/10.1590/1676-0611-bn-2019-0905 Weiler, D.A.; Giacomini, S.J.; Aita, C.; Schmatz, R.; Pilleco, G.E.; Chaves, B.; Bastos, L.M. 2019. Summer cover crops shoot decomposition and nitrogen release in a notilled sandy soil. Revista Brasileira Ciência do Solo, 43: e0190027. DOI: https://doi. org/10.1590/18069657rbcs20190027

Recibido: 21 de febrero de 2021 Aceptado para publicación: 6 de julio de 2021 